\title{
Efektivitas Model Pembelajaran Blended Learning dalam Meningkatkan Kemandirian dan Hasil Belajar Peserta Didik pada Masa Pandemi Covid-19
}

\author{
Nur Lailatul Mufidah ${ }^{*}$, Jun Surjanti² \\ 1,2Universitas Negeri Surabaya, Surabaya - Indonesia
}

\section{A R T I C L E I N F O}

\section{Article history:}

Received April, 302021

Received in revised form May, 202021

Accepted May, 252021

Available online June, 28 2021

\section{Kata Kunci:}

Blended learning,

kemandirian, hasil belajar.

Keywords:

Blended learning

independent learning,

learning outcomes.

\begin{abstract}
A B S T R A K
Riset ini bertujuan untuk menganalisis efektivitas model pembelajaran Blended Learning yang diterapkan pada masa pandemi covid-19 dan dilihat berdasarkan respon peserta didik. Selain itu, riset ini juga bertujuan menganalisis seberapa efektif model Blended Learning mampu meningkatkan kemandirian belajar serta hasil belajar peserta didik. Riset ini termasuk kedalam jenis penelitian kuantitatif yang menggunakan pendekatan quasi eksperimen dengan rancangan Posttest Only Control Group Design. Populasi dalam penelitian ini adalah kelas XI IPS SMAN 1 Puri, Mojokerto. Teknik Sampling yang digunakan adalah teknik Simple Random Samping dan diperoleh kelas XI IPS 1 sebagai kelas kontrol dan XI IPS 3 sebagai kelas Eksperime. Data penelitian bersumber dari data primer dan sekunder. Data primer berasal dari nilai posttest, kuisioner kemandirian dan respon peserta didik. Sedangkan data sekunder diperoleh berdasarkan dokumentasi pada nilai dan absensi kehadiran peserta didik. Riset ini berhasil membuktikan bahwa pembelajaran blended learning dapat terlaksana dengan persentase sebesar 95,83\%. Efektivitas model Blended learning menunjukkan persentase sebesar 73,84\%. Implementasi model Blended Learning juga efektif meningkatkan kemandirian belajar yang ditunjukkan pada nilai Sign $(2$-tailed $)$ adalah $0,021<0,05$, dan juga dapat meningkatkan hasil belajar peserta didik yang ditujukkan pada pada nilai Sign (2-tailed) adalah 0,032<0,05.
\end{abstract}

\section{A B S T R A C T}

This research aims to analyze the effectiveness of the Blended Learning learning model that was applied during the Covid-19 pandemic and is seen based on the responses of students. In addition, this research also aims to analyze how effectively the Blended Learning model is able to increase learning independence and student learning outcomes. This research belongs to the type of quantitative research that uses a quasi-experimental approach with a Posttest Only Control Group Design. The population in this study was class XI IPS at SMAN 1 Puri, Mojokerto. The sampling technique used was the Simple Random Side technique and obtained class XI IPS 1 as the control class and XI IPS 3 as the Experiment class. The research data comes from primary and secondary data. Primary data comes from posttest scores, independence questionnaires and student responses. Meanwhile, secondary data was obtained based on documentation on the value and attendance of students. This research succeeded in proving that blended learning learning could be carried out with a percentage of $95.83 \%$. The effectiveness of the Blended learning model shows a percentage of $73.84 \%$. The implementation of the Blended Learning model is also effective in increasing learning independence which is shown in the Sign value (2-tailed) is $0.021<0.05$, and can also improve student learning outcomes shown in the Sign (2-tailed) value is 0.032 $<0,05$.

Copyright (C Ekuitas: Jurnal Pendidikan Ekonomi. All rights reserved.

\footnotetext{
* Corresponding author.

E-mail : nlmufidah22@gmail.com (Nur Lailatul Mufidah)
} 


\section{Pendahuluan}

Pandemi covid-19 berhasil mengubah kehidupan sebagian besar penduduk di dunia dalam berbagai bidang dan sektor, tidak terkecuali dibidang pendidikan (Rachmawati et al., 2020). Covid -19 merupakan virus baru yang secara struktural berkaitan dengan virus yang menyebabkan pernafasan akut yang parah atau sindrom SARS (Fauci et al., 2020). Pendidikan di masa pandemi berpeluang besar mengancam kualitas pendidikan di seluruh dunia, UNESCO mengungkap bahwa virus corona menyebabkan 577 juta pelajar di dunia dengan total 39 negara melakukan penutupan sekolah, termasuk Indonesia (Wakhudin et al., 2020). Segala upaya pemutusan penyebaran rantai virus corona telah dilakukan pemerintah, salah satunya yaitu dengan menerapkan kebijakan $3 \mathrm{M}$, yang meliputi menggunaan masker, Menjaga jarak aman dan membersihkan telapak tangan. Sejalan dengan kebijakan tersebut, Menteri Pendidikan dan Kebudayaan juga mengeluarkan kebijakan yaitu mewajibkan semua satuan pendidikan untuk melaksanakan proses pembelajaran dari rumah. Dengan adanya kebijakan tersebut, proses pembelajaran di sekolah banyak mengalami perubahan, misalnya guru tidak lagi dapat melaksanakan pembelajaran tatap muka secara utuh tetapi diganti dengan pembelajaran daring atau pembelajaran jarak jauh. Kemudian guru diharuskan untuk menerapkan model pembelajaran yang tepat dan tidak bertentangan dengan kebijakan pemerintah.

Pembelajaran daring dirasa tepat untuk diterapkan sebagai pembelajaran jarak jauh (Chick et al., 2020). Menurut Muhammad dalam (Sukirwan, 2020) ada berbagai aplikasi yang bisa digunakan oleh para pendidik untuk melakukan pembelajaran daring seperti, whatsupp, google meeting, zoom meeting, google classroom, quipeer dan sebagainya. Pembelajaran daring tidak dapat sepenuhnya diterapkan secara terus menerus, sejalan dengan hasil penelitian Damayanthi (2020) yang mengungkapkan sebanyak 48\% mahasiswa tidak setuju pembelajaran daring diterapkan secara permanen. Kemudian diperkuat dengan penelitian Wijaya (dalam Damayanthi, 2020) bahwa tidak semua mahasiwa dapat memahami materi yang diberikan dalam pembelajaran daring, sehinggga pembelajaran tatap muka tetap dibutuhkan.

Dengan situasi dan kondisi saat ini, model pembelajaran blended learning dirasa tepat dan dapat dijadikan alternatif model belajar yang mampu memadukan proses belajar secara sinkron dan asinkron. Graham (2005) mendefinisikan pengertian dari blended menjadi tiga definisi, yaitu pencampuran media interaksi pembelajaran, perpaduan pendekatan atau metode pembelajaran, dan kombinasi pelajaran online dan tatap muka. Howard (dalam Chaeruman, 2019) menjelaskan bahwa Blended Learning diartikan sebagai dua pengaturan pembelajaran yaitu pembelajaran sinkronus dan asinkronus. Littlejohn \& Pegler (dalam Standard \& Numbers, 2008) menjelaskan pembelajaran sinkonus merupakan pembelajaran yang yang dilakukan secara bersamaan pada jam yang sama meskipun ada pada lokasi yang berbeda. Kegiatan belajar sinkronus terdapat dua jenis. Pertama adalah proses belajar sinkronus dengan tatap muka secara langsung di kelas (Heinich et al., 2012). Kedua yaitu sinkronus online atau virtual (Staley, 2007). Sedangkan pembelajaran asinkronus merupakan kegiatan belajar mengajar pada materi yang sama namun berada pada tempat dan waktu yang berlainan (Heinich et al., 2012). Dalam penerapannya, proses pembelajaran yang efektif merupakan proses belajar yang didalamnya mengimplementasikan suatu model yang mampu menghantarkan pesrta didik dalam mencapai target belajar yang diinginkan, salah satunya diwujudkan dari hasil belajar yang maksimal. Garner \&Oke (2014) mengungkapkan bahwa Blended Learning merupakan lingkungan pembelajaran yang disusun dengan maksud untuk memperoleh hasil yang maksimal. Lebih lanjut pemberlakuan model Blended Learning juga bertujuan untuk meningkatkan kesempatan bagi mahasiswa atau peserta didik agar dapat belajar dengan mandiri (Darma et al., 2020)

Kemandirian belajar menjadi faktor penting dalam proses pembelajaran(Yuliati \& Saputra, 2020). Model blended learning dapat membantu peserta didik memahami bagaimana menjadi pembelajar mandiri yang berpusat pada siswa (Watson et al., 2020). Menurut Hamka, D. \& Vilmala, B.K. (dalam Yuliati \& Saputra, 2020), kemandirian belajar diartikan sebagai pemahaman atas dirinya untuk tidak menggantungkan dirinya kepada orang lain dan bertanggungjawab dalam mewujudkan target yang diharapkan. Hasil riset yang dilakukan Yuliati \& Saputra (2020) memaparkan bahwa model pembelajaran yang dapat menjadikan peserta didik mengalami peningkatan kemandirian belajar adalah model pembelajaran Blended Learning, sekaligus dapat dijadikan alternative pilihan model pembelajaran yang dapat diimplementasikan selama masa pandemic covid-19 berlangsung. Dalam hal ini kemandirian belajar peserta didik dapat tercermin melalui keinginan untuk belajar tanpa diperintah, menyelesaikan setiap masalah, dan bertanggung jawab atas kewajibannya sebagai peserta didik. Dalam kenyataannya fenomena kemandirian belajar pada diri peserta didik masih kurang terlebih dengan proses pembelajaran secara daring. Dari kegiatan observasi dan wawancara dengan guru ekonomi di SMAN 1 Puri didapatkan hasil yang menyatakan bahwa kebanyakan peserta didik akan belajar hanya menjelang ujian, kemudian ketika pembelajaran daring, seperti halnya guru mengirimkan materi pada goolge 
classroom yang wajib dipelajari oleh peserta didik, akan tetapi tidak sedikit peserta didik yang mendownload materi saja tanpa membaca, atau ketika pembelajaran dilakukan secara sinkronus menggunakan google meet atau zoom, banyak peserta didik yang tidak focus mendengarkan dan memahami penjelasan guru dengan melakukan aktivitas lain yang dilakukan secara bersamaan, diperkuat lagi dengan tingkat partisipasi atau keaktifan peserta didik selama pembelajaran berlangsung tidak lebih dari $50 \%$, yang artinya rerata peserta didik menunjukkan sikap dan partisipasi yang pasif. Hal - hal tersebut mengindikasi bahwa kemandirian belajar peserta didik yang masih rendah. Sedangkan (Novitayati, 2013) mengatakan bahwasanya kemandirian belajar adalah variabel penting yang mempengaruhi hasil belajar.

Selain kemandirian belajar, Blended learning juga memungkinkan guru untuk mempersonalisasi pendidikan untuk meningkatkan prestasi dan keterlibatan akademik siswa (Watson et al., 2020). Pernyataan tersebut selaras dengan temuan Aziz (2013) bahwasanya penerapan blended learning mampu memaksimalkan hasil belajar siswa. Didukung oleh penelitian López-pérez, dkk (2011) bahwa model Blended Learning memiliki pengaruh positif dalam meningkatkan hasil belajar. Hasil belajar diartikan sebagai bentuk transformasi sikap dan perbuatan peserta didik setelah mendapatkan pembelajaran. Hasil belajar dapat tercermin dalam penilaian ulangan harian, nilai UTS maupun nilai UAS. Menurut keterangan dari guru ekonomi SMAN 1 Puri, semenjak merebahnya wabah virus corona maka proses belajar mengajar dilaksanakan secara daring. Secara keseluruhan hasil belajar peserta didik selama pembelajaran daring mengalami perubahan, ditunjukkan pada nilai peserta didik pada mata pelajaran ekonomi yang mengalami penurunan, dan hanya sekitar 30\% peserta didik yang mendapatkan nilai diatas Ketuntasan Belajar Minimal (KBM). Melalui implementasi model Blended Learning diharapkan nilai atau hasil beljar peserta didik dapat mengalami peningkatan. KD inflasi merupakan materi yang cukup dirasa sulit bagi peserta didik yang tercermin dari penilaian harian yang rata - rata tidak dapat memenuhi Ketuntasan Belajar Minimal (KBM).

Riset ini memiliki tujuan untuk menganalisis keterlaksanan proses belajar mengajar melalui model Blended learning dan menganalisis seberapa efektif model ini untuk diterapkan pada peserta didik yang dilihat berdasarkan respon peserta didik, peningkatan kemandirian belajar dan hasil belajar. Riset ini diharapkan mampu mendorong peserta didik mengikuti proses pembelajaran Blended Learning dengan baik agar terjadi peningkatan pada kemandirian dan hasil belajar. Lebih lanjut, Hasil riset ini juga diharapkan dapat berguna bagi pendidik atau guru dan berbagai pihak yang berkaitan untuk menambah kualitas pengajaran dengan menerapkan model Blended learning selama pandemi covid-19 berlangsung.

\section{Metode}

Riset ini termasuk kedalam jenis penelitian kuantitatif yang menggunakan pendekatan quasi eksperimen dengan rancangan Penelitian Posstest Only Control Group Design. Dalam hal ini peneliti akan memberikan treatment yaitu perlakuan model Blended Learning untuk kelas eksperimen. Kelas kontrol hanya menggunakan pembelajaran daring melalui grup Whatsapp saja atau tidak diberi treatment yang sama sebagaimana kelas eskperimen.

Riset dilaksanakan di SMAN 1 Puri, Mojokerto yang berlokasi di JL. Jayanegara Nomor 02, Gatul, Banjaragung, Puri, Mojokerto. Populasi dalam penelitian adalah seluruh kelas Xl IPS SMAN 1 Puri, kemudian dilakukan pengambilan sampel penelitian menggunakan teknik pengampilan sampel acak (Simple Random Sampling). Berdasarkan pengambilan sampel yang dilakukan didapatkan kelas XI IPS 1 sebagai kelas kontrol dan XI IPS 3 selaku kelas eskperimen.

Pengumpulan data dilakukan menggunakan instrumen wawancara, lembar pengamatan keterlaksanaan pembelajaran, kuisioner, dokumentasi dan tes. Proses wawancara dilakukan dengan guru ekonomi guna memperoleh informasi yang berterkaitan dengan permasalahan yang dihadapi peserta didik selama pembelajaran jarak jauh. Lembar observasi keterlaksanaan pembelajaran digunakan sebagai pedoman penilaian untuk mengukur kesesuaian antara RPP dan proses pembelajaran yang berlangsung. Kuisioner digunakan untuk melihat tingkat kemandirian belajar juga respon peserta didik. Dan instrument tes yang berupa posttest digunakan dalam mengukur hasil belajar. Sebelum kuisioner disebarkan pada peserta didik maka dilakukan pengujian validitas dan reliabilitas instrument terlebih dahulu, dan untuk posttest dilakukan pengujian daya beda sekaligus tingkat kesukaran soal.

Analisis data pengukuran keterlaksanaan pembelajaran dihitung menggunakan rumus sebagai berikut :

Persentase Keterlaksanaan Pembelajaran $=\frac{j \text { wmiah item terlaksana }}{\text { jumlah item keseluruhan }} x 100 \%$, 
Selanjutnya dihitung rata-rata persentase keterlaksanaan setiap pertemuan dengan rumus berikut :

$$
\mathrm{Xp}_{\mathrm{k}}=\frac{A p k}{\mathrm{n}},
$$

Rata - rata persentase keterlaksanaan tersebut digunakan untuk mengkategorikan keberhasilan pembelajaran yang telah dilaksanakan. Berikut ini kriteria rata - rata presentas keterlaksanaan pembelajaran:

Tabel 1. Kriteria Keterlaksanaan Pembelajaran

\begin{tabular}{cc}
\hline Intreval & Kriteria \\
\hline $75<\mathrm{Xpk} \leq 100$ & Baik \\
$50<\mathrm{Xpk} \leq 75$ & Cukup Baik \\
$25<\mathrm{Xpk} \leq 50$ & Kurang Baik \\
$0<\mathrm{Xpk} \leq 25$ & Buruk \\
\hline
\end{tabular}

Selanjutnya, analisis data respon peserta didik terhadap pembelajaran Blended Learning dihitung menggunakan rumus sebagai berikut:

$$
\text { Respon }(\%)=\frac{\text { jumilah shor } \text { Total }}{\text { jumilah shor Ideal }} X 100 \%
$$

Setelah diperoleh persentase respon peserta didik, selanjutnya dapat dikategorikan rata-rata respon peserta didik tersebut sesuai tabel dibawah ini:

Tabel 2. Kriteria Respon Peserta Didik

\begin{tabular}{cc}
\hline Rentang Persentase & Kriteria \\
\hline $0 \%-20 \%$ & Sangat Kurang \\
$21 \%-40 \%$ & Kurang \\
$41 \%-60 \%$ & Cukup \\
$61 \%-80 \%$ & Baik \\
$81 \%-100 \%$ & Sangat Baik \\
\hline
\end{tabular}

(Riduwan, 2010)

Dalam riset ini, pengujian hipotesis menggunakn Uji Independent Sample t Test. Pengujian hipotesis dilakukan guna mengetahui perbedaan rerata tingkat kemandirian belajar dan hasil belajar antara kelas eksperimen dan kelas kontrol. Sebelum uji t maka dilakukan pengujian pra-syarat terlebih dulu pada data yang diperoleh yaitu uji normalitas dan uji homogenitas. Pengujian ini berguna untuk mengetahui data yang diperoleh terdistribusi normal atau tidak, homogen atau tidak. Kedua uji tersebut merupakan syarat mutlak yang harus dipenuhi sebelum melakukan uji T Test.

\section{Hasil dan pembahasan}

\section{Hasil Penelitian}

\section{Analisis Data Hasil Observasi Keterlaksanaan Pembelajaran}

Keterlaksanaan pembelajaran model blended learning pada kelas Eksperimen dapat diketahui dari lembar observasi keterlaksanaan pembelajaran yang sudah diamati oleh observer. Analisis data hasil keterlaksanaan pembelajaran dapat dihitung berdasarkan indikator terlaksana dalam setiap pertemuannya. Berikut persentase keterlaksanaan pembelajaran model Blended Learning pada kelas eksperimen : 
Tabel 3. Keterlaksanaan Pembelajaran Blended Learning

\begin{tabular}{rcc}
\hline Pertemuan 1 & Pertemuan 2 & Pertemuan 3 \\
\hline $100 \%$ & $100 \%$ & $87,50 \%$ \\
\hline
\end{tabular}

Selanjutnya, berdasarkan persentase keterlaksanaan pembelajaran pada setiap petemuan dihitung rata-rata persentase keterlaksanaan tersebut menggunakan rumus :

$$
\mathrm{Xp}=\frac{A p k}{n}=\frac{a g 7_{x} 5}{a}=95,83 \%
$$

Rata - rata persentase keterlaksanaan pembelajaran blended learning adalah 95,83\% yang dapat dikategorikan baik. Hal tersebut menunjukkan bahwa pelaksanaan proses pembelajaran dengan strategi Blended Learning sudah terlaksa dan selaras dengan RPP yang dibuat dan keterlaksanaan pembelajaran dikategorikan terlaksana dengan baik.

\section{Analisis efektivitas Blended Ditinjau dari Respon Peserta didik}

Efektivitas suatu model pembelajaran selain dilihat dari tercapainya tujuan belajar, juga diketahui dari respon peserta didik setelah mengikuti poses pembelajaran sesuai model yang diterapkan (Baroh, 2010). Dalam menentukan kriteria respon peserta didik dapat dilakukan dengan menghitung persentase setiap item pernyataan dan disajikan dalam tabel 4 .

Tabel 4. Persentase Respon Peserta Didik

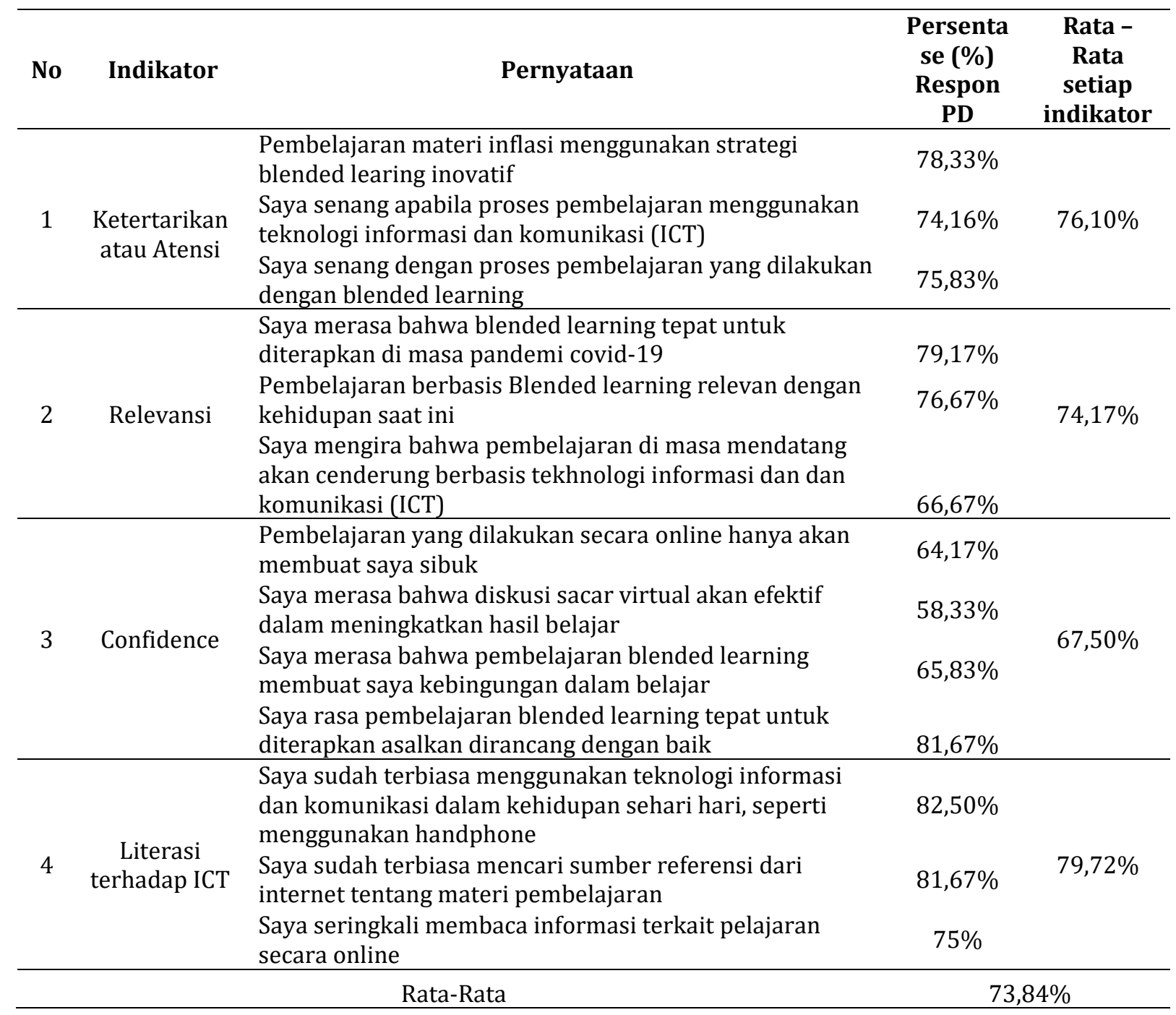


Berdasarkan tabel 4, diketahui respon siswa terhadap pembelajaran Blended Learning secara keseluruhan rata-rata sebesar 73,84\% dan dikategorikan baik. Efektivitas model Blended Learning yang dilihat dari respon peserta didik dapat dilihat dari 4 indikator. Indikator ketertarikan rata-rata sebesar $76,10 \%$, indikator relevansi sebesar $74,17 \%$, indikator confidence senilai $67,5 \%$, dan indikator literasi terhadap ICT senilai 79,72\%.

\section{Analisis data Kemandirian Belajar}

Kemandirian belajar adalah bentuk kesadaran terhadap diri sendiri untuk tidak menggantungkan diri kepada orang lain dan bertanggungjawab atas ketercapaian tujuan dalam belajar. Sebelum melakukan uji hpotesis, maka data yang didapatkan dilakukan pengujian pra-syarat terlebih dahulu. Hasil uji prasyarat disajikan dalam tabel 5 dan 6, seperti berikut :

Tabel 5. Hasil Uji Normalitas

\begin{tabular}{llrc}
\hline & Kelas & $\begin{array}{c}\text { Kolmogorov- } \\
\text { Smirnov } \\
\text { Sig. }\end{array}$ & $\begin{array}{c}\text { Shapiro- } \\
\text { Willk } \\
\text { Sig. }\end{array}$ \\
\hline $\begin{array}{l}\text { Kemandirian } \\
\text { Belajar }\end{array}$ & $\begin{array}{l}\text { Kelas } \\
\text { Ekperimen }\end{array}$ & $.200^{*}$ & .621 \\
& Kelas Kontrol & $.200^{*}$ & .275 \\
\hline
\end{tabular}

Berdasarkan tabel 5, ditunjukkan nilai Sign pada pengujian di atas yaitu Sign $>0,05$. Untuk kelas eksperimen nilai Sign 0,621 > 0,05 dan kelas kontrol 0,275 > 0,05. Dapat ditarik kesimpulan bahwa kedua data terdistribusi normal, baik kelas kontrol maupun kelas ekserimen.

Tabel 6. Hasil Uji Homogenitas

\begin{tabular}{lccccc}
\hline & & $\begin{array}{c}\text { Levene } \\
\text { Statistic }\end{array}$ & df1 & df2 & Sig. \\
\hline $\begin{array}{l}\text { Kemandirian } \\
\text { Belajar }\end{array}$ & Based on Mean & .099 & 1 & 58 & .754 \\
\hline
\end{tabular}

Berdasarkan tabel diatas diketahui nilai Sign yaitu 0,754 > 0,05. Sehingga dapat diambil kesimpulan bahwa data antara kelas eksperimen dan kelas kontrol sejenis atau homogen. Berdasarkan hasil kedua uji prasyarat diatas, dapat diketahui bahwa kedua syarat mutlak untuk dapat melakukan uji independen sampe $t$ test telah dipenuhi, sehingga dapat dilakukan ke uji tahap selajutnya. Berikut hasil uji Independent Sampe t test:

Table 7. Hasil Uji Independent Sample t test

\begin{tabular}{|c|c|c|c|c|c|c|c|}
\hline & $\mathrm{F}$ & Sig. & $\mathrm{t}$ & $\mathrm{df}$ & $\begin{array}{l}\text { Sig. (2- } \\
\text { tailed) }\end{array}$ & $\begin{array}{l}\text { mean } \\
\text { diference }\end{array}$ & $\begin{array}{l}\text { Std. Error } \\
\text { Difference }\end{array}$ \\
\hline Kemandirian & .099 & .754 & 2.374 & 58 & .021 & 4.567 & 1.924 \\
\hline Belajar & & & 2.374 & 57.976 & .021 & 4.567 & 1.924 \\
\hline
\end{tabular}

Berdasarkan uji t test diketahui nilai Sign (2-tailed) adalah 0,021<0,05, menunjukkan adanya perbedaan rata-rata kemandirian belajar kelas kontrol dan kelas eksperimen. Ditunjukkan pada rata-rata kelas eksperimen yaitu 46,37 dan rata-rata untuk kelas kontrol 41,80. Terjadi peningkatan yang signifikan pada perolehan tingkat kemandirian belajar kelas eksperimen yang mendapatkan perlakuan dibandingkan dengan kelas kontrol.

\section{Analisis data Hasil Belajar}

Hasil belajar didefinisikan sebagai bentuk transformasi sikap atau perilaku peserta didik setelah mendapatkan pembelajaran. Guru akan melakukan evaluasi pembelajaran untuk mengetahui hasil belajar peserta didik. Hasil belajar data dilihat berdasarkan nilai PTS maupun PAS. Dalam riset ini hasil belajar 
peserta didik terlihat pada nilai Posttest yang dilakukan pada kelas kontrol dan kelas eksperimen. Berikut hasil pengujian normalitas dan homogenitass data hasil belajar:

Tabel 8. Hasil Uji Normalitas Hasil Belajar

\begin{tabular}{|c|c|c|c|}
\hline & \multirow{2}{*}{ Kelas } & $\begin{array}{c}\text { Kolmogorov- } \\
\text { Smirnov }^{\mathrm{a}}\end{array}$ & $\begin{array}{c}\text { Shapiro- } \\
\text { Wilk }\end{array}$ \\
\hline & & Sig. & Sig. \\
\hline Nilai & Kelas & $200^{*}$ & 681 \\
\hline Post & Eksperimen &.$\angle 00$ & .081 \\
\hline Test & kelas Kontrol & 195 & .362 \\
\hline
\end{tabular}

Berdasarkan tabel 8 diatas menunjukkan nilai Sign $>0,05$, oleh sebab itu dapat diambil kesimpulan bahwa data hasil belajar berupa nilai posttest terdistribusi normal.

Table 9. Hasil Uji Homogenitas

\begin{tabular}{llrrrr}
\hline & & $\begin{array}{c}\text { Levene } \\
\text { Statistic }\end{array}$ & $\mathrm{df1}$ & $\mathrm{df2}$ & Sig. \\
\hline $\begin{array}{l}\text { Nilai } \\
\text { Post } \\
\text { Test }\end{array}$ & $\begin{array}{l}\text { Based } \\
\text { on Mean }\end{array}$ & .544 & 1 & 58 & .464 \\
\hline
\end{tabular}

Pengujian homogenitas dilakukan untuk menjelaskan data antara kelas kontrol dan kelas eksperimen homogen atau heterogen. Pada tabel 9 dapat dilihat nilai dari Based on mean memiliki nilai Sign 0,464 $>0,05$, sehingga kedua varian data adalah homogeny atau sejenis. Kemudian dilakukan pengujian hipotesis untuk mengetahui selisih hasil belajar kelas kontrol dan kelas eksperimen.

Table 10. Hasil Uji Independent Sample t test

\begin{tabular}{|c|c|c|c|c|c|c|c|}
\hline & $\mathrm{F}$ & Sig. & $\mathrm{t}$ & $\mathrm{df}$ & $\begin{array}{l}\text { Sig. (2- } \\
\text { tailed) }\end{array}$ & $\begin{array}{l}\text { mean } \\
\text { diference }\end{array}$ & $\begin{array}{l}\text { Std. Error } \\
\text { Difference }\end{array}$ \\
\hline Hasil & .544 & .464 & 2.196 & 58 & .032 & 7.700 & 3.507 \\
\hline Belajar & & & 2.196 & 57.446 & .032 & 7.700 & 3.507 \\
\hline
\end{tabular}

Berdasarkan hasil uji t, dapat dilihat nilai Sign (2-tailed) adalah 0,032 < 0,05, oleh karena itu ditarik kesimpulan bahwa terdapat perbedaan rata-rata kelas kontrol dan kelas eksperimen. Rata - rata nilai posttest untuk kelas kontrol yaitu 63,93 dan kelas eksperimen adalah 71,63. Dengan demikian dapat dikatakan bahwa penerapan model Blended Learning berpengaruh terhadap peningkatan hasil belajar ekonomi

\section{Pembahasan \\ Keterlaksanaan Pembelajaran}

Keterlaksanaan suatu proses pembelajaran dapat dilihat berdasarkan lembar observasi keterlaksanaan pembelajaran yang telah diamati oleh observer. Observer dalam penelitian ini yaitu guru mata pelajaran ekonomi yaitu Bapak Debi Ruli Sandi, S.Pd. Pengamatan keterlaksanaan pembelajaran dilakukan pada kelas eksperimen yakni kelas Xl IPS 3 SMAN 1 Puri. kelas XI IPS 3 sebagai kelas eksperimen berjumlah 30 peserta didk yang mencakup 19 siswa perempuan dan1 11 siswa laki-laki, sedangkan kelas XI IPS 1 sebagai kelas kontrol berjumlah 30 peserta didik yang mencakup 9 siswa lakilaki dan 21 siswa perempuan.

Dalam lembar observasi keterlaksanaan pembelajaran terdapat tiga aspek utama yang diamati oleh observer yaitu meliputi aspek pembelajaran asinkron mandiri, sinkronus virtual dan asinkron kolaboratif. Pembelajaran sinkronus virtual mencakup kegiatan pendahuluan, kegiatan inti dan penutup. Proses pembelajaran KD inflasi dilakukan tiga kali pertemuan. Pertemuan pertama mendiskusikan materi 
pokok indeks harga, pertemuan kedua membahas inflasi dan pertemuan ketiga membahas mengenai cara mengatasi inflasi yaitu kebijakan moneter dan fiskal.

Pertemuan pertama diselengarakan Rabu, 3 Maret 2021 pukul 07.00 sampai 08.30 dengan materi pokok indeks harga. Pada kegiatan asinkron mandiri peserta didik diinformasikan untuk mempelajari serta mendowload studi kasus mengenai kenaikan harga emas dan rokok melalui google classroom sehari sebelum pembelajaran virtual (Tahapan seeking of Information) dan dibentuk kelompok menjadi 6 kelompok. Selanjutnya pada pembelajaran sinkronus virtual dilaksanakan menggunakan aplikasi google meeting. Pada pembelajaran virtual mencakup kegatan pembuka, inti dan penutup. Kegiatan pembuka diawali dengan ucapan salam dan berdoa yang kemudian dilanjutkan dengan kegiatan apersepsi dan penyampaian tujuan pembelajaran. Dilanjutkan pada kegiatan inti dimana guru menampilkan power point tentang materi inflasi dan membahas studi kasus yang sudah diberikan pada saat pembelajaran asiknron mandiri (Acquisition of information). Pada tahapan ini peserta didik diberi kesempatan untu melakukan tanya jawab terkait materi yang kurang jelas dan diakhiri dengan kesimpulan mengenai materi yang telah didiskusikan (Synthesizing of knowledge). Kemudian dibagian penutup peserta didik di intruksikan untuk membuat power point bersama kelompok tentang studi kasus yang diberikan. Selanjutnya kegiatan asinkronus kolaboratif yaitu peserta didik bersama kelompok mengerjakan tugas yang telah diintruksikan dan mengumpulkannya di google classroom.

Pertemuan kedua diselenggarakan Rabu, 10 Maret 2021 pukul 07.00 sampai 08.30 dengan materi pokok inflasi. Pertemuan kedua sama halnya dengan pertemuan ketiga dimana terdapat tiga kegiatan belajar mengajar yaitu kegiatan asinkron mandiri, sinkrous virtual dan asinkron kolaboratif. Pada hari selasa malam peserta didik diinformasikan bahwa proses belajar mengajar pada hari rabu akan dilaksanakan menggunakan google meeting melalui Whatsapp group. Tahapan kegiatan pembelajaran Blended Learning pada materi pokok inflasi memiliki tahpan yang sama dengan pertemuan pertama, yang membedakan hanya pada studi kasus yang diberikan yaitu mengenai Kinerja Ekonomi Jatim Triwulan II2020 Mengalami Kontraksi yang didalamnya membahas mengenai inflasi yang terjadi di jawa timur.

Pertemuan ketiga diselenggarakan Rabu, 17 Maret 2021 pukul 07.00 sampai 08.30 dengan materi pokok kebijakan fiskal dan moneter sebagai langkah dalam mengatasi inflasi. Kegiatan asinkron mandiri dilaksanakan pada malam hari menjelang pembelajaran sinkronus virtual, dimana peserta didik diinformasikan untuk mengikuti pembelajaran virtual menggunakan google meeting dan diinstruksikan untuk mempelajari link video yang ditelah diunggah di google classroom dan mencatat pertanyaan yang perlu ditanyakan saat pembelajaran secara virtual. Pada kegiatan sinkronus virtual dilakukan proses pembelajaran menggunakan google meeting. Pada kegiatan pendahuluan diawali dengan doa dan dilakukan kegiatan apersepsi, selanjutnya pada kegiatan inti dijelaskan cara mengatasi inflasi melalui kebijakan monete dan fiscal dengan media power point. Peserta didik diberikan kesempatan untuk Tanya jawab terkait materi yang kurang jelas atau menanyakan terkait video yang sudah dipelajari. Pada bagian penutup, guru dan peserta didik memberi kesimpulan atas materi yang dipelajari secara bersama dan peserta didik diberi tugas mengerjakan latihan soal di LKPD dan diskusi bersama temannya sebagai bentuk kegiatan pembelajaran asinkron kolaboratif.

Berdasarkan tabel lembar observasi keterlaksanaan pembelajaran dipaparkan bahwa pada pertemuan pertama, keterlaksanaan pembelajaran Blended Learning yaitu $100 \%$ yang artinya semua aspek dalam lembar observasi dilakukan secara keseluruhan tanpa ada tahapan pembelajaran yang terlewatkan. Pada pertemuan kedua juga didapatkan hasil yang sama dimana nilai persentase keterlaksanaan pembelajaran Blended Learning yaitu 100\% yang artinya semua aspek dan tahapan pembelajaran dilaksanakan dengan baik. Sedangkan dalam pertemuan ketiga, persentase keterlaksanaan pembelajaran yaitu 87,5\% yang artinya terdapat tahapan atau kegiatan yang tidak dilaksanakan seuai dengan rencana pelaksanaan pembelajaran. Tahapan yang tidak dilaksanakan yaitu mereview tugas peserta didik dan memberikan penilaian. Kegiatan tersebut tidak dilaksanakan dikarenakan peseta didik tidak ada yang mengerjakan dan mengumpulkan tugas sampai batas waktu yang ditentukan, sehingga tahapan tersebut tidak dilaksanakan.

Apabila dilihat secara keseluruhan berdasarkan persentase keterlaksanaan pembelajaran pada setiap pertemuan dapat dilihat bahwa nilai mean keterlaksanaan pembelajaran model Blended Learning pada pelajaran ekonomi yaitu 95,83 dan dikategorikan baik. Dengan demikian dapat disimpulkan bahwa berdasarkan lembar observasi keterlaksanaan pembelajaran yang telah diamati oleh obsever dalam hal ini guru mata pelajaran ekonomi SMAN 1 Puri menunjukkan hasil yang menyatakan bahwasanya pembelajaran yang dilakukan menggunakanm model Blended Learning dapat terlaksana dengan baik dengan nilai persentase senilai $95,83 \%$. 


\section{Efektivitas Model Blended Learning}

Efektifitas model blended learning salah satunya dilihat berdasarkan respon peserta didik setelah memperoleh pembelajaran. Dalam penelitian ini respon yang diperoleh hanya berasal dari kelas eksperimen yang mendapatkan perlakuan (Treatment). Pada hasil yang diperoleh, diketahui respon peserta didik terhadap pemblajaran Blended Learning dikategorikan baik yaitu dengan persentase $73,84 \%$. Respon peserta didik didasarkan pada empat indikator. Indikator pertama yaitu atensi atau ketertarikan terhadap pelajaran ekonomi yang dilakukan secara Blended Learning. Ketertarikan peserta didik pada pembelajaran yang dilakukan dengan Blended Learning sebesar 76,10\% dan dikatehgorikan respon yang baik, yang artinya hampir seluruh siswa senang dan tertarik dengan pembelajaran yang dilakukan dengan Blended Learning yang mamanfaatkan penggunaan tekhnologi informasi dan komunikasi. Ketertarikan yang tingi terhadap penerapan Blended Learning merupakan titik awal yang positif. Marzano (1993) menyatakan bahwa sikap yang positif dalam pembelajaran adalah fokus yang pertama dari lima dimensi belajar agar efektif.

Indikator kedua yaitu Relevansi yang terdiri atas tiga item pertanyaan. Dari ketiga pernyataan tersebut diperoleh tingkat relevansi peserta didik terhadap penerapan Blended Learning sebesar 74,17\% dan dikategorikan baik. Yang artinya penerapan Blended learning dianggap relevan untuk diterapkan dengan kehidupan saat ini yang cenderuung berbasis ICT dan tepat untuk diimplementasikan selama pandemi Covid-19.

Indikator ketiga yaitu confidence atau kepercayaan diri yang memiliki persentase rata-rata dari keempat item pernyataan yaitu 67,5\%. Dalam indikator ini peserta didik merasa bahwa pembelajaran saat ini yang dilakukan dengan Blended Learning cukup membuat mereka sibuk dan kebingungan sehingga rata-rata peserta didik merasa tidak cukup mampu untuk dapat meningkatkan hasil belajar. Meski demikian, mereka yakin bahwa dengan model Blended Learning yang dirancang dengan baik dapat diterapkan dan memperoleh hasil yang maksimal.

Indikator terakhir yaitu literasi terhadap teknologi informasi dan komunikasi yang menunjukkan persentase rata-rata sebesar $79,72 \%$. Artinya sebagian besar peserta didik sudah terbiasa memanfaatkan penggunaan tekhnologi informasi dan komunikasi dalam proses pembelajaran. Misalnya mereka terbiasa menggunakan ponsel untuk komunikasi jarak jauh dan mencari informasi terkait pembelajaran yang sulit dipahami di internet.

Berdasarkan keseluruhan respon yang diberikan peserta didik terkait penerapan model Blended Learning dapat diketahui bahwa respon yang diberikan peserta didik rata-rata sebesar $73,84 \%$ dan dikategorikan Baik. Dapat disimpulkan bahwa implementasi model Blended Learning pada pelajaran ekonomi khususnya KD Inflasi yang apabila ditinjau dari respon peserta didik dapat dikatakan efektif untuk diterapakan di masa pandemi Covid-19.

\section{Analisis Kemandirian Belajar}

Berdasarkan tabel 7 menujukkan nilai Sign (2-tailed) adalah 0,021 yang kurang dari taraf signifikasi 0,05 yaitu $0,021<0,05$, yang artinya ditemukan adanya selisih mean tingkat kemandirian belajar pserta didik. Pada tabel 7 diketahui nilai rata-rata kelas kontrol adalah 42,86667 dan 46,36667 untuk kelas eksperimen. Dapat diketahui juga bahwa mean rata-rata kelas eksperimen lebih unggul dari pada kelas kontrol. Skor total yang diperoleh kelas kontrol adalah 1.286, sedangkan pada kelas eksperimen adalah 1.391. kedua data menunjukkan adanya selisih cukup signifikan untuk rata - rata tingkat kemandirian belajar.

Berdasarkan deskripsi data diketahui adanya perbedaan tingkat kemandirian belajar yang dibuktikan pada perolehan rata-rata maupun skor total kemandirian belajar kelas eksperimen yang lebh unggul. Artinya perlakuan model Blended learning pada kelas eksperimen terbukti dapat meningkatkan kemandirian belajar peserta didik. Sehingga bisa dikatakan perlakuan model Blended Learning berpengaruh terhadap peningkatan kemandirian belajar Kelas XI IPS di SMAN 1 Puri, Mojokerto. Hal ini bermakna bahwa hipotesis H1 diterima, yang artinya hasil penelitian berhasil membutikan bahwa ditemukan selisih yang signifikan pada kelas kontrol dan kelas eksperimen dalam perolehan kemandirian belajar.

Hasil penelitian menjelaskan bahwa dengan diterapkannya Model Blended learning pada kelas XI IPS 3 SMAN 1 Puri berpengaruh terhadap peningkatan kemandirian belajar. Pada kelas kontrol guru hanya melakukan pembelajaran melalui google classroom dan whatsapp group, sedangkan untuk kelas eksperimen, peneliti menerapkan model Blended Learning yaitu dengan memadukan pembelajaran secara asinkron dan sinkronus virtual melalui google classroom, whatssup group dan google meeting. Pada kelas eksperimen, siwa lebih aktif untuk mengikuti proses pembelajaran yang dilakukan dengan perlakuan Blended Learning. Hal ini disebabkan mereka merasa bahwa dengan disertainya pembelajaran virtual dapat memberikan kesempatan untuk tanya jawab secara langsung terkait materi yang tidak 
dapat dipahami. Sedangkan pada kelas kontrol materi hanya disampaikan melalui google classroom saja tanpa disertai pembelajaran virtual, sehingga peserta didik merasa tidak berkesan atau malas untuk belajar. Dengan adanya keterbatasan kondisi saaat ini, maka penerapan model pembelajaran yang tepat sangat diperlukan oleh peserta didik guna dapat belajar secara aksimal dan target yang diinginkan tercapai. Selaras dengan pernyataan Aunurrohman (2013) bahwa penggunaan model pembelajaran yang sesuaii dapat menumbuhkan rasa cinta dan ketertarikan siswa pada pelajaran sehingga dapat memperoleh nilai yang maksmimal.

Sehingga disimpulkan bahwa pnerapan model Blended Learning efektif dalam meningkatkan tingkat kemandirian belajar peserta didik pada mata pelajaran ekonomi di SMAN 1 Puri, Mojokerto selama masa pandemi covid-19. Didukung oleh penelitian (Ningsih et al., 2017) bahwa terdapat kenaikan tingkat kemandirian belajar pada mahasiwa yang mendapatkan Blended Learning dibandingkan proses pembelajaran biasa. Uz \& Uzun (Uz \& Uzun, 2018) juga menyatakan bahwasanya Blended Learning berpengaruh terhadap kemandirian belajar yang ditunjukkan dengan skor kemandirian belajar kelas eksperimen lebih unggul dari kelas kontrol. Diperkuat lagi oleh (Fitriasari \& Sari, 2017) dan (Farida \& Indah, 2019) yang berhasil membuktikan bahwa kemandirian belajar dapat mengalami peningkatan akibat adanya implementasi model Blended Learning.

\section{Analisis Hasil Belajar}

Berdasarkan tabel 10, memaparkan nilai Sign (2-tailed) 0,032 tidak lebih dari taraf signifikasi 0,05 yaitu $0,32<0,05$, bermakna bahwa terlihat adanya perbedaan nilai posttest diantara kedua kelas. Dapat ditunjukkan berdasarkan mean atau nilai rata-rata yaitu sebesar 63,93 untuk kelas kontrol dan 71,63 untuk kelas eksperimen. Terdapat peningkatan sebesar 7,7 atau sekitar 12,04\%.

Berdasarkan pemaparan data di atas diketahui hasil posttest kelas eksperimen lebih tinggi apabila disejajarkan dengan kelas kontrol. Artinya kelas yang mendapatkan perlakuan Blended Learning memperoleh hasil belajar yang maksimal dan menunjukkan bahwa perlakuan model Blended Learning dapat berpengaruh pada peningkatan hasil belajar peserta didik Hal ini membuktikan bahwa penerapan model Blended Learning di masa pandemi covid-19 berpengaruh terhadap peningkatan hasil belajar ekonomi. Selanjutnya dapat disimpulkan bahwa Hipotesis $\mathrm{H} 2$ diterima, yang artinya implementasi model Blended learning pada mata pelajran ekonomi kelas XI IPS SMAN 1 Puri, Mojokerto berhasil menunjukan adanya perbedaan signifikan pada rerata hasil belajar kelas kontrol dan kelas eksperimen atas penerapan model tersebut.

Hasil penelitian membuktikan bahwa dengan diterapkannya model Bleded Learning, peserta didik dapat memperoleh hasil maksimal dibandingkan dengan pembelajaran daring yang hanya melalui google classroom dan whatsapp group seperti yang dilakukan kelas kontrol. Nilai post test kelas kontrol tidak lebih baik dibandingkan kelas eksperimen. Pada kelas kontrol, nilai posttest teringgti yaitu 87 dan yang terendah yaitu 33. Sedangkan nilai posttest tertinggi pada kelas eksperimen yaitu 93 dan yang terendah adalah 43. Sekitar $13 \%$ dari total jumlah peserta didik pada kelas kontrol yang dapat memenuhi Ketuntasan Belajar Mimimum yaitu 78. Sedangkan pada kelas eksperimen sekitar 30\% dari total jumlah siswa yang memenuhi Ketuntasan Belajar Minimum (KBM).

Dalam penelitian ini nilai post test dapat dijadikan sebagai pengukuran ketercapaian hasil belajar siwa. Pada kelas eksperimen, peserta didik dapat melakukan kegiatan tanya jawab secara virtual melalui google meeting mengenai materi ekonomi yang sulit dimengerti. Pembelajaran virtual dapat menggantikan pembelajaran tatap muka secara langsung dikelas karena keterbatsan kondisi pandemi saat ini. Sehingga meski pembelajaran dilakukan jarak jauh, peserta didik tetap bisa melakukan proses belajar mengajar dengan lancar dan mendapatkan hasil belajar yang maksimal melalui penerapan model Blended Learning. Sebaliknya, pada kelas kontrol peserta didik hanya diberi materi melalui google classroom untuk dipahami secara mandiri tanpa adanya pembelaran virtual, hal ini menyebabkan peserta didik tidak memiliki akses yang lebih luas untuk melakukan Tanya jawab secara virtual kepada guru terkait materi yang belum dipahami. Oleh karenanya perolehan hasil belajar kelas kontrol lebih baik dari kelas eksperimen.

Dengan demikian berdasarkan uji hipotes yang telah dilakukan dapat dinyatakan bahwasanya perlakuan Model Blendeng Learning berpengaruh pada peningkatan hasil belajar ekoomi di SMAN 1 Puri, Mojokerto. Selain itu penerapan model Blended Learning juga efektif untuk diterapkan pada masa pandemi ditunjukkan dengan adanya peningkatan hasil belajar ekonomi. Hasil penelitian ini didukung oleh (Wai et al., 2014) yang menyatakan bahwa proses belajar mengajar dengan model Blended Learning efektif meningkatkan hasil belajar. Selain itu (Kazu \& Demirkol, 2014) juga menyatakan bahwasanya hasil belajar kelas eksperimen jauh lebih unggul daripada pembelajaran konvensional atau tradisional. Diperkuat lagi oleh (Fajar \& Riantika, 2019) yang mengungkapkan bahwa implementasi model Blended Learning berhasil meningkatkan hasil belajar peserta didik secara signifikan. 


\section{Simpulan dan saran}

Berdasarkan deskripsi data dan pemaparan di atas, dapat disimpulkan bahwa : (1) Pelaksanaan implementasi Model Blended Learning pada kelas eksperimen yaitu XI IPS 3 terselenggara dengan baik. Ditunjukkan dengan persentase rata-rata keterlaksanaan pada setiap pertemuannya adalah sebesar 93,83\% yang didasarkan pada lembar observasi keterlaksanaan pembelajaran yang telah diamati oleh pengamat. (2) Efektivitas Model Blended Learning yang ditinjau dari respon peserta didik selama proses pembelajaran menunjukkan bahwa persentase respon peserta ddik yaitu sebesar $73,84 \%$ dan kategorikan baik. Sehingga penerapan model Blended Learning efektif untuk diterapkan di masa pandemi Covid-19. (3) Implementasi model pembelajaran Blended Learning efektif dalam peningkatan kemandirian belajar pserta didik kelas XI IPS 3 pada pelajaran ekonomi di SMAN 1 Puri, Mojokerto. (4) ) Implementasi model pembelajaran Blended Learning efektif dalam peningkatan hasil belajar peserta didik kelas XI IPS 3 SMAN 1 Puri, Mojokerto.

Berdasarkan simpulan-simpulan di atas, maka disarankan: (1) Model pembelajaran Blended Learning dapat diimplementasikan pada seluruh mata pelajaran, tidak hanya pelajaran ekonomi. Karena model Blended Learning efektif untuk diterapkan selama pandemi Covid-19 dan efektif dalam peningkatan kemandirian dan hasil belajar peserta didik. (2) Hasil penelitian ini dapat dikembangkan dan disempurnakan dalam pengkajian yang lebih luas terkait efektivitas Model pembelajaran Blended Learning yang dapat dilihat dari variabel lain selain kemandirian dan hasil belajar.

\section{Daftar Rujukan}

Aunurrohman. (2013). Belajar dan Pembelajaran. Alfabeta.

Azis, Y. M. (2013). the Effectiveness of Blended Learning, Prior Knowledge. Contemporary Issues In Education Research, 2(2), 106-116.

Baroh, C. (2010). Efektivitas Metode Stimulasi dalam Pembelajaran Matematika pada Pokok Bahasan Peluang di Kelas IX-A MTS Nurul Huda Kalanganyar Sedati Sidoarjo. Skripsi Pendidikan Mateatika.

Bonk, C. J., Graham, C. R., Cross, J., \& Moore, M. G. (2005). The Handbook of Blended Learning: Global Perspectives, Local Designs. Pfeiffer.

Chaeruman, U. A. (2019). Merancang Model Blended Learning Designing Blended Learning Model. Jurnal Teknodik, 17(4), 053. https://doi.org/10.32550/teknodik.v17i4.577

Chick, R. C., Clifton, G. T., Peace, K. M., Propper, B. W., Hale, D. F., Alseidi, A. A., \& Vreeland, T. J. (2020). Using Technology to Maintain the Education of Residents During the COVID-19 Pandemic. Journal of Surgical Education, 77(4), 729-732. https://doi.org/10.1016/j.jsurg.2020.03.018

Damayanthi, A. (2020). Efektivitas Pembelajaran Daring di Masa Pandemi Covid 19. JURNAL SOSIAL :Jurnal Penelitian Ilmu-Ilmu Sosial, 21(3), 53-56.

Darma, I. K., Karma, I. G. M., \& Santiana, I. M. A. (2020). Blended Learning, Inovasi Strategi Pembelajaran Matematika di Era Revolusi Industri 4.0 Bagi Pendidikan Tinggi. Prosiding Seminar Nasional Pendidikan Matematika, 3, 527-539.

Fajar, R., \& Riantika, P. (2019). Efektivitas Model Pembelajaran Blended Learning untuk Meningkatkan Hasil Belajar Geografi pada Materi Litosfer Kelas X SMA. 2, 1723-1729.

Farida, A., \& Indah, R. P. (2019). Penerapan Blended Learning Untuk Peningkatan Kemandirian Belajar Dan Critical Thinking Mahasiswa. Jurnal Derivat: Jurnal Matematika Dan Pendidikan Matematika, 5(2), 19-27. https://doi.org/10.31316/j.derivat.v5i2.138

Fauci, A. S., Lane, H. C., \& Redfield, R. R. (2020). Covid-19 - Navigating the Uncharted. New England Journal of Medicine, 382(13), 1268-1269. https://doi.org/10.1056/nejme2002387

Fitriasari, P., \& Sari, N. (2017). Implementasi blended learning untuk meningkatkan kemandirian belajar mahasiswa pada mata kuliah metode numerik. Prosiding Seminar Nasional Pendidikan Matematika 2017, 2010, 1-10.

Garner, B., \& Oke, L. (2014). Blended Learning:Theoretical Foundation. Indiana Wesleyan University.

Heinich, R., Molenda, M., Russell, J., \& Smaldino, S. (2012). Instructional Media and Technology for Learning. International Journal of Distributed and Parallel Systems, 3, 8.

Kazu, I. Y., \& Demirkol, M. (2014). EFFECT OF BLENDED LEARNING ENVIRONMENT MODEL ON HIGH SCHOOL STUDENTS ' ACADEMIC ACHIEVEMENT. The Turkish Online Journal of Educational Technology, 13(1), 78-87.

López-pérez, M. V., Pérez-lópez, M. C., \& Rodríguez-ariza, L. (2011). Blended learning in higher education : Students ' perceptions and their relation to outcomes. Computers \& Education, 56(3), 818-826. https://doi.org/10.1016/j.compedu.2010.10.023

Marzano, R. ., Pickering, D., \& McTighe, J. (1993). Assessing Students Outcomes,Performance Assessment 
Using The Dimensions of Learning Model. ASCD.

Ningsih, Y. L., Misdalina, M., \& Marhamah, M. (2017). Peningkatan Hasil Belajar dan Kemandirian Belajar Metode Statistika Melalui Pembelajaran Blended Learning. Al-Jabar : Jurnal Pendidikan Matematika, 8(2), 155. https://doi.org/10.24042/ajpm.v8i2.1633

Novitayati, R. (2013). Pengaruh Metode Blended Learning dan Self Regulated Learning Terhadap Hasil Belajar Kognitif IPS. Jurnal Penelitian Pendidikan, 1, 48-57.

Rachmawati, Y., Ma'arif, M., Fadhillah, N., Inayah, N., Ummah, K., Siregar, M. N. F., Amalyaningsih, R., C., F. A. A., \& F., A. A. (2020). Studi Eksplorasi Pembelajaran Pendidikan IPA Saat Masa Pandemi COVID-19 di UIN Sunan Ampel Surabaya. Indonesian Journal of Science Learning, Volume 1,(1), 32-36.

Riduwan. (2010). Skala Pengkuran Variabel-variabel Penelitian. Alfabeta.

Staley, L. (2007). Where Mind Meet.

Standard, I., \& Numbers, B. (2008). Brescia-2008-British_Journal_of_Educational_Technology. British Journal of Educational Technology, 39(4), 117-129.

Sukirwan. (2020). PEMBELAJARAN DARI RUMAH DARI KLASIKAL KE DIGITAL. Akrab Juara, 5(1), 43-54.

Uz, R., \& Uzun, A. (2018). The Influence of Blended Learning Environment on Self-Regulated and SelfDirected Learning Skills of Learners. European Journal of Educational Research, 7(4), 877-886. https://doi.org/10.12973/eu-jer.7.4.877

Wai, C. C., Lim, E., \& Seng, K. (2014). Exploring the effectiveness and efficiency of blended learning tools in a school of business. Procedia - Social and Behavioral Sciences, 123(2002), 470-476. https://doi.org/10.1016/j.sbspro.2014.01.1446

Wakhudin, Romadlon, F., Sirega, J., Firmansyah, Sani, R. A., Pangarso, A., Hart, J., Rusnedy, R., Purnomo, M., Nuvriasari, A., Harsoyo, T. D., Mirdayanti, R., Retnoningtia, D. W., Hardika, I. R., Sahrah, A., \& Abdul, S. V. P. | R. A. | T. N. E. D. S. | M. O. L. | D. R. P. R. | M. R. R. | R. Y.| S. L. C. | E. A. | A. S. | A. N. (2020). Dalam Ragam Tinjauan (D. H. Santoso \& A. Santosa (eds.)). MBridge Press.

Watson, J., Powell, A., Staley, P., Patrick, S., Horn, M., Fetzer, L., Hibbard, L., Oglesby, J., Verma, S., Education, M., C, T. O. C.-I. N. B., Kuehn, B. L., Ed, D., Archibald, D., Barbour, M. K., Leary, H., Wilson, E. V., \& Ostashewski, N. (2020). Teacher education and K-12 online learning. INACOL, The International Association for K-12 Online Learning, July, 1-20.

Yuliati, Y., \& Saputra, D. S. (2020). Membangun Kemandirian Belajar Mahasiswa Melalui Blended Learning Di Masa Pandemi Covid-19. Jurnal Elementaria Edukasia, 3(1), 142-149. 